\title{
Prevalence and Risk Factors for Development of Asymptomatic Bacteriuria Among HIV Positive Pregnant Women in Jos, Nigeria
}

\author{
Tinuade Abimbola Oyebode ${ }^{1,2, ~ *}$, Godwin Imade ${ }^{1}$, Isichei Christian ${ }^{1,3}$, Tolulope Afolaranmi ${ }^{1,4}$, \\ Halima Sule $^{1,5}$, Jonah Musa ${ }^{1,2}$, Solomon Sagay ${ }^{1,2}$, Prosper Okonkwo ${ }^{6}$, Demetrios Kyriacou ${ }^{7}$, \\ Chad Achenbach $^{8}$, Phyllis Kanki ${ }^{9}$ \\ ${ }^{1}$ Faculty of Medical Sciences, University of Jos, Jos, Nigeria \\ ${ }^{2}$ Department of Obstetrics and Gynaecology, Jos University Teaching Hospital, Jos, Nigeria \\ ${ }^{3}$ Department of Chemical Pathology, Jos University Teaching Hospital, Jos, Nigeria \\ ${ }^{4}$ Department of Community Medicine, Jos University Teaching Hospital, Jos, Nigeria \\ ${ }^{5}$ Department of Family Medicine, Jos University Teaching Hospital, Jos, Nigeria \\ ${ }^{6}$ AIDS Prevention Initiative in Nigeria (APIN), Abuja, Nigeria \\ ${ }^{7}$ Department of Emergency Medicine, Northwestern University Feinberg School of Medicine, Northwestern University, Chicago, USA \\ ${ }^{8}$ Division of Infectious Diseases and Center for Global Health, Northwestern University Feinberg School of Medicine, Northwestern \\ University, Chicago, USA \\ ${ }^{9}$ Infectious Diseases \& Immunology, Harvard School of Public Health, Boston, USA
}

\section{Email address:}

tinuadeoyebode@yahoo.com (T. A. Oyebode), ereimade@gmail.com (G. Imade), christianisichei@yahoo.com (I. Christian), toluene42002@gmail.com (T. Afolaranmi), haltsav@yahoo.com (H. Sule), drmusaj@yahoo.com (J. Musa), atsagay@yahoo.com (S. Sagay), pokonkwo@apin.org.ng (P. Okonkwo),d-kyriacou@northwestern.edu (D. Kyriacou), c-achenbach@northwestern.edu (C. Achembach), pkanki@hsph.harvard.edu (P. Kanki)

${ }^{*}$ Corresponding author

\section{To cite this article:}

Tinuade Abimbola Oyebode, Godwin Imade, Isichei Christian, Tolulope Afolaranmi, Halima Sule, Jonah Musa, Solomon Sagay, Prosper Okonkwo, Demetrios Kyriacou, Chad Achenbach, Phyllis Kanki. Prevalence and Risk Factors for Development of Asymptomatic Bacteriuria Among HIV Positive Pregnant Women in Jos, Nigeria. Central African Journal of Public Health. Vol. 7, No. 4, 2021, pp. 170-181. doi: 10.11648/j.cajph.20210704.14

Received: June 7, 2021; Accepted: June 19, 2021; Published: June 25, 2021

\begin{abstract}
The Human Immunodeficiency Virus pandemic is negatively affecting the reproductive health of women in Nigeria. It is associated with increased morbidity and mortality, especially where secondary infections exist. Studies document that HIV positive women are prone to reproductive and urinary tract infections, and due to physiologic changes in pregnancy, there is higher incidence of urinary infections among pregnant women, with or without symptoms. This prospective cohort study investigates for asymptomatic bacteriuria in pregnancy among HIV seropositive women, to identify if HIV positivity confers additional risks for occurrence. We recruited 119 pregnant HIV positive women and 152 HIV negative controls from Jos University teaching hospital and Faith Alive hospital in Jos, Nigeria and screened for asymptomatic bacteriuria. Bacteriuria was confirmed when two separate urine samples, in the same woman, showed presence of $10^{5} \mathrm{CFU} / \mathrm{ml}(100,000$ organisms $)$ of same species. Laboratory personnel performing tests were unaware of participants HIV status. Antibiotic sensitivity were determined and participants were followed-up/evaluated for features of pyelonephritis throughout antenatal care. Prevalence was determined and analysis to determine if HIV positivity conferred risks. There were 22 women with confirmed bacteriuria, with prevalence of $8.1 \%$ among all participants, with 9.4\% (14) among HIV Negative cohort and $6.8 \%$ (8) of HIV positive women. HIV status, demography and previous pyelonephritis/UTI were not statistically associated with development of asymptomatic bacteriuria. Two women with medical conditions (Diabetes and Sickle cell disease) had confirmed bacteriuria, but numbers were insufficient to deduce an association. Staphylococcus aureus predominated (78.6\%) among HIV negative, while for HIV positive women, Escherichia coli and Staphylococcus aureus each affected $44.4 \%$. Antibiotic sensitivity
\end{abstract}


favoured Cefuroxime in both HIV positive and negative women, but organisms were resistant to penicillins and Nitrofurantoin. Treatment was not possible because of antibiotics cost and/or unwillingness of participants to receive treatment for an asymptomatic condition. Analysis of the HIV positive cohort showed no further conferment of risk by $\mathrm{CD}_{4}$ counts, viral load, duration of HIV positivity, the anti-retroviral drug type/class or duration/adherence to ARVs. No woman with $\mathrm{CD}_{4}$ count $>500$ cells $/ \mathrm{mm}^{3}$ developed asymptomatic bacteriuria but there was no statistical association. Similarly, women who had undetectable viral load had lower bacteriuria rates, while women with high viral load had higher rates of asymptomatic bacteriuria, but this was only significant when analysis was performed using the logarithm of viral load.

Keywords: Asymptomatic Bacteriuria, Urine, Culture, Pregnancy, HIV Positive, Pyelonephritis, $\mathrm{CD}_{4} \mathrm{Count}$

\section{Introduction}

The pandemic of the Human Immunodeficiency Virus infection and the Acquired Immune Deficiency Syndrome (HIV/AIDS) is having a ruinous effect on the reproductive health of women in Nigeria [1-4], and is associated with increased perinatal and maternal morbidity and mortality especially where secondary infections supervene [4-6]. HIV positive women are prone to infections of the reproductive tract, other body systems [2, 4], and urinary tract infections [7]. The incidence is also higher in pregnant women, irrespective of presence of symptoms due to the physiologic changes in pregnancy [8-12].

Untreated asymptomatic bacteriuria $(\mathrm{AB})$ has been associated with higher episodes of pyelonephritis [13-17]. Other studies found associations with anaemia, pre-eclampsia chronic pyelonephritis, preterm labour and low birth weight $[16,18-21]$, but there is no universal consensus regarding complications of untreated asymptomatic bacteriuria [17, 21].

The prevalence of asymptomatic bacteriuria $(\mathrm{AB})$ in pregnancy varies depending on the population studied. The concept of AB was first introduced by Edward Kass in 1956 [22] who defined it as the presence of at least $10^{5}(100,000)$ organisms per $\mathrm{ml}$ of clean catch urine in the absence of obvious symptoms of UTI during pregnancy or the pueperium if untreated [22]. His pioneering work discovered that $6 \%$ of pregnant women had asymptomatic bacteriuria in pregnancy with increased incidence of prematurity and perinatal mortality compared with those with sterile urine [22]. In Nigeria, different studies with different methodologies have found different rates ranging from $4.8 \%$ [17] to $8 \%$ [13] and in some cases $14 \%[23,24]$. A study in Benin City found a prevalence of $86.6 \%$ among their pregnant women [20], however, only one sample of cleancatch early morning urine was cultured and those with $10^{5}$ bacteria per $\mathrm{ml}$ of urine were taken as significant asymptomatic bacteriuria. The factors that predispose to bacteriuria in pregnancy are hormonal changes and mechanical factors, which lead to stasis, increased $\mathrm{pH}$, glycosuria and impaired bladder emptying [8, 15].

The most frequently isolated uropathogen in pregnant women is Escherichia coli [8, 15]. Other Enterobacteria are (Klebsiella, Enterobacter and Proteus), then Staphylococcus epidermidis, Staphylococcus saprophyticus, Enterococcus faecalis and group B Streptococcus [8, 10, 12, 15]. The optimal time for screening was proposed as 16 weeks of gestation [8], as asymptomatic bacteriuria is said to be invariably present at the initial visit and only $1 \%$ of women are said to acquire $\mathrm{AB}$ later in pregnancy. Screening at this gestation will only be possible where women book for antenatal care early enough, which does not happen in our environment. Screening by urine culture is time consuming and expensive but appears to be cost effective when the prevalence is about 5-9\% [19]. Rapid screening Dip Stick methods using Multistix will be cheaper, but there is reduced sensitivity and tests are only positive with Gram-negative organisms or presence of pyuria [19]. Urine culture may still be the first choice in this environment where prevalence rates of up to $14 \%$ were obtained in previous studies [24].

Research is a major compliment of any HIV/AIDS control measure [25], thus investigating for asymptomatic bacteriuria among HIV seropositive women in pregnancy, in order to identify consequences that may militate against delivery of a healthy offspring, is justified. This study will equip antenatal care providers with prevalence rates and determine if HIV seropositivity confers additional risk. The findings will inform recommendations for routine screening of all pregnant women for asymptomatic bacteriuria, prescriptions of prophylactic urinary antiseptics or antibiotics during antenatal care as well as scale-up of care to improve quality of life. The incidence is also higher among low socioeconomic status groups and in women with sickle cell traits [26], both of which are present in our antenatal women cohorts.

So far, studies to determine association between asymptomatic bacteriuria and HIV seropositive pregnant women are still few or non-existent. Considering that awareness and attitude of Nigerian pregnant women towards HIV screening and investigations have been found to be good, especially among educated women [27, 28], a platform to study asymptomatic bacteriuria in pregnant HIV seropositive women has been created. Spence and other workers found a prevalence of $15.9 \%$ of $\mathrm{AB}$ among non-pregnant HIV positive women [29]. There was no significant difference between age, race, ethnicity, immune or haematological parameters. They concluded that there is higher prevalence of $\mathrm{AB}$ among HIV positive women, but recommended more studies in the area [29]. HIV associated nephropathy (HIVAN) is a known complication in HIV/AIDS patients, where there is increased loss of renal function and increased risk of mortality due to the cytopathic effect of HIV on kidney cells expressing $\mathrm{CD}_{4}$ molecules [9]. However, this is yet to be 
shown to be associated with increased incidence of asymptomatic bacteriuria.

The Center for Disease Control (CDC) categorized HIV disease into category $\mathrm{A}\left(\mathrm{CD}_{4}>500\right.$ cells $\left./ \mathrm{mm}^{3}\right)$, Category B $\left(200-499\right.$ cells $\left./ \mathrm{mm}^{3}\right)$ and Category $\mathrm{C}\left(<200\right.$ cells $\left./ \mathrm{mm}^{3}\right)$, and these symptom categories are recommended to guide clinical and therapeutic actions in management of HIV infected patients [30]. The progression of HIV immunosuppression has significant inverse relationship to $\mathrm{CD}_{4}$ lymphocyte count, but the less available viral load testing is a stronger predictor [30]. Few studies exist to show correlation between asymptomatic bacteriuria and $\mathrm{CD}_{4}$ count and viral load, even though low $\mathrm{CD}_{4}$ count and high viral load are associated with increased rates of maternal morbidity [31].

The introduction of highly active antiretroviral therapy (HAART) for the treatment of HIV/AIDS has reduced HIV morbidity and mortality by suppressing viral loads to undetectable levels, improving immune status and reducing the incidence of opportunistic infections [32].

Multiple antiretroviral drugs in different classes have been approved [32]. They include the Nucleoside Reverse Transcriptase Inhibitors (NRTI), the Non-Nucleoside Reverse Transcriptase Inhibitors (NNRTI), the Protease Inhibitors (PI), Fusion Entry Inhibitors and other newer ones [32, 33]. However, adverse clinical events including the AIDS related insulin resistance and the lipodystrophy syndrome have been observed in $30-80 \%$ of patients who are well controlled with HAART [32, 33]. Hyperglycaemia (in 3-17\%), worsening glucose control, development of new onset diabetes mellitus (DM), and diabetic keto acidosis have been associated with patients receiving HAART, particularly with use of protease inhibitors [33]. Glycosuria increases incidence of bacteriuria in pregnancy [8], but studies are yet to demonstrate increased incidence of $\mathrm{AB}$ among this group of women on HAART and this requires investigation.

The purpose of the research is to determine the local prevalence rate of asymptomatic bacteriuria, if it increases risks of developing clinical urinary tract infection or pyelonephritis. The study will also determine if HIV positive women are more at risk of developing bacteriuria and pyelonephritis, considering that they are at higher risks of developing infections, which can be life threatening. This will guide health providers regarding routine screening of HIV positive women for asymptomatic bacteriuria and treating those found positive.

\section{Study Design and Participants}

This study was carried out at the antenatal Clinics (ANC) and the Prevention of Mother to Child transmission (PMTCT) of HIV clinics of the Jos University Teaching Hospital (JUTH), as well as the Faith Alive hospital, Jos (a Christian non-governmental charity hospital). The two facilities have the highest load of Antenatal care and PMTCT patients in Plateau State. The PMTCT Programs receive support from the US President's Plan for AIDS relief (PEPFAR), through collaborations with Harvard School of Public Health USA and AIDS Prevention Initiative in Nigeria (APIN). Patients are referred here from the various hospitals in and out of Plateau State. This prospective cohort study entailed collaboration between the clinical, nursing and laboratory staff of the PMTCT and ANC clinics of both hospitals. The researcher provided the funds for materials and incentives.

Questionnaires were pretested at a Primary Health Care (PHC) center and results imputed into questionnaire/study design. The purpose of the study was explained to all, and participants and witnesses were required to sign informed consent forms, with the non-educated women did thumb printing. Patients were informed about freedom to withdraw from the study without prejudice to their expected standard of care. Relevant data was collected by nurses and trained counselors of the PMTCT/ANC clinics, who could also communicate in local dialects.

\subsection{Recruitment}

Convenience sampling was used to recruit willing seropositive pregnant women attending the PMTCT booking clinics into the study. Controls were age and parity matched HIV seronegative patients also attending the ANC booking clinic. This was done until minimum sample size was obtained. Women aged 18 years and above, carrying singleton pregnancy who were between 16-32 weeks of pregnancy were eligible for inclusion. Those with symptoms suggestive of UTI including dysuria, loin pain, fever, suprapubic pain, and increased urinary frequency were excluded, as well as women who had received antibiotics for whatever reason within the past one month were excluded from the study. Women who had history of preterm delivery before 37 weeks, those presenting with features of preterm delivery, women with uncertain HIV status, those with background renal disease and other medical conditions were also excluded from the study. We offered the women free screening for asymptomatic bacteriuria, a test that is not routinely available to them outside the study. All women provided signed informed consent before participating in the study. The study got approval from the research ethics committee of Jos University teaching hospital and the institutional review board of Faith Alive Foundation Hospital.

\subsection{Primary and Secondary Outcomes}

The primary outcome for both the HIV positive and HIV negative cohorts was the occurrence of asymptomatic bacteriuria. The secondary outcomes we looked for were adverse maternal outcomes of features of acute pyelonephritis or urinary tract infection. We defined acute pyelonephritis as two or more of-fever (temperature $\geq 38.0^{\circ} \mathrm{C}$ ), symptoms of pyelonephritis (nausea, vomiting, chills, and renal angle tenderness), and a positive urine culture indicating the presence of bacteria. We defined urinary tract infection as a clinical report of a urinary tract infection that was treated with antibiotics. In all participants, outcome data were recorded on questionnaires completed by the participants together with the nurse/counselors, and updated 
as participants were reviewed at ANC/PMTCT clinics during the course of the pregnancy.

\subsection{Sample Collection and Processing}

Consenting participants were taught to collect clean catch specimen of urine. This involved self-cleaning of perineum with $500 \mathrm{mls}$ of water that was provided, then they voided the initial few mls of urine into the bathroom, after which 10 mls of midstream urine was collected into sterile universal bottles we provided. All were in accordance with standard laboratory requirements, and urine samples were transported to the laboratory in ice packed coolers to avoid bacterial multiplication at room temperature. All women were asked to return one week later for results.

The urine was examined microscopically, then cultured on McConkey, Cled and Blood Agar. Colonies from media plates with growth were identified and colony-forming organisms per milliliter $(\mathrm{CFU} / \mathrm{ml})$ were determined. All women who had their first urine samples culture positive $(1 \times$ $10^{5} \mathrm{CFU} / \mathrm{mL}$ ), had a second sample of midstream urine collected the next week, and repeat microscopy, culture and this time antibiotic sensitivity were conducted. Asymptomatic bacteriuria was accessed to be present when two separate urine samples in the same woman showed presence of $10^{5}$ organisms $\left(1 \times 10^{5} \mathrm{CFU} / \mathrm{mL}\right)$ of the same species in both specimens. Sensitivity tests were determined by using multidisc, to determine antibiotics patients will benefit from. Treatment of culture positive cases will be based on sensitivity pattern.

\subsection{Data Collection and Analysis}

The study sample size was calculated from prevalence rates obtained in Nigerian studies, where values were between $4.8 \%[17]$ to $14 \%[23,24]$. The calculated sample size was 113 to be recruited into each of the HIV positive and negative arms of the study. We screened 334 women, but excluded 46 who had the exclusion criteria including recent antibiotic treatment, known renal disease, abnormal vaginal discharge. Samples of the remaining 288 were obtained but 17 samples were assessed to be contaminated or compromised and screened out, so the study participants were 271, and 119 were HIV Positive while 152 were HIV Negative. The urine culture method was utilized based on recommendations of a cost benefit analysis which indicated that if asymptomatic bacteriuria rates were greater than $9 \%$, screening with culture was more cost effective, while it is cost beneficial to screen with dipsticks if rates were greater than $2 \%$ [27].

The difference in the proportion of primary outcomes between asymptomatic bacteriuria-positive and asymptomatic bacteriuria-negative women were analyzed for HIV status and other variables including demographic parameters, marital settings and practices, parity, gestational age, past history of UTI. Thereafter, the use and duration of $\mathrm{ARV}, \mathrm{CD}_{4}$ count and viral load were analyzed for the HIV positive women. The association between asymptomatic bacteriuria and the participants' variables were analyzed using the Chi square tables, students' $\mathrm{T}$ test of the Epi-Info and Stata statistical packages. The Yates corrected Chi square and the Fischer's exact tables were utilized when indicated. Confidence intervals of $95 \%$ were used when appropriate, and $\mathrm{P}$ values less than 0.05 were judged to be statistically significant. Analysis were carried out to determine if asymptomatic bacteriuria conferred risk for acute pyelonephritis and pre-eclampsia, since it was found to constitute $25-30 \%$ risk factor for developing symptomatic urinary tract infection (UTI) during pregnancy [20] and may be associated with adverse effects on maternal and fetal health $[8,20]$.

Table 1. Socio-demographic characteristics of the respondents.

\begin{tabular}{lll}
\hline Characteristics & Frequency & Percentage n=271 \\
\hline Age Group (years) & 230 & 84.9 \\
$\leq 34$ & 41 & 15.1 \\
35 and above & Mean \pm SD & \\
Mean age & $28.5 \pm 5.4$ years & 2.6 \\
Marital Status & 7 & 94.5 \\
Single & 756 & 0.7 \\
Married & 2 & 2.2 \\
Divorced & 6 & 69.7 \\
Widowed & & 30.3 \\
Religion & 189 & 90.0 \\
Christianity & 22 & 10.0 \\
Islam & & \\
Primary Family Type & 244 & 3.3 \\
Monogamy & 27 & 1.8 \\
Polygamy & & 24.4 \\
Highest Level of Education Attained & 9 & 38.0 \\
None & 5 & 32.5 \\
Informal & 66 & \\
Primary & 103 & \\
Secondary & 88 & \\
Tertiary & & \\
Highest Level of Education Attained by the husband & & \\
\hline
\end{tabular}




\begin{tabular}{lll}
\hline Characteristics & Frequency & Percentage n=271 \\
\hline None & 11 & 4.0 \\
Informal & 2 & 0.7 \\
Primary & 31 & 11.4 \\
Secondary & 114 & 42.1 \\
Tertiary & 113 & 41.7 \\
Estimated gestational age at booking (weeks) & & \\
$\leq 13$ weeks & 23 & 8.5 \\
$14-26$ weeks & 146 & 53.9 \\
27 weeks and above & 102 & 37.6 \\
& Mean \pm SD & \\
Mean gestational age at booking & $23.7 \pm 7.3$ weeks & 19.2 \\
Parity & & 27.3 \\
Nulliparous & 52 & 38.4 \\
Primiparous & 74 & 15.1 \\
$2-4$ & 104 & \\
$\geq 5$ & 41 & \\
\hline
\end{tabular}

$\mathrm{SD}=$ Standard Deviation.

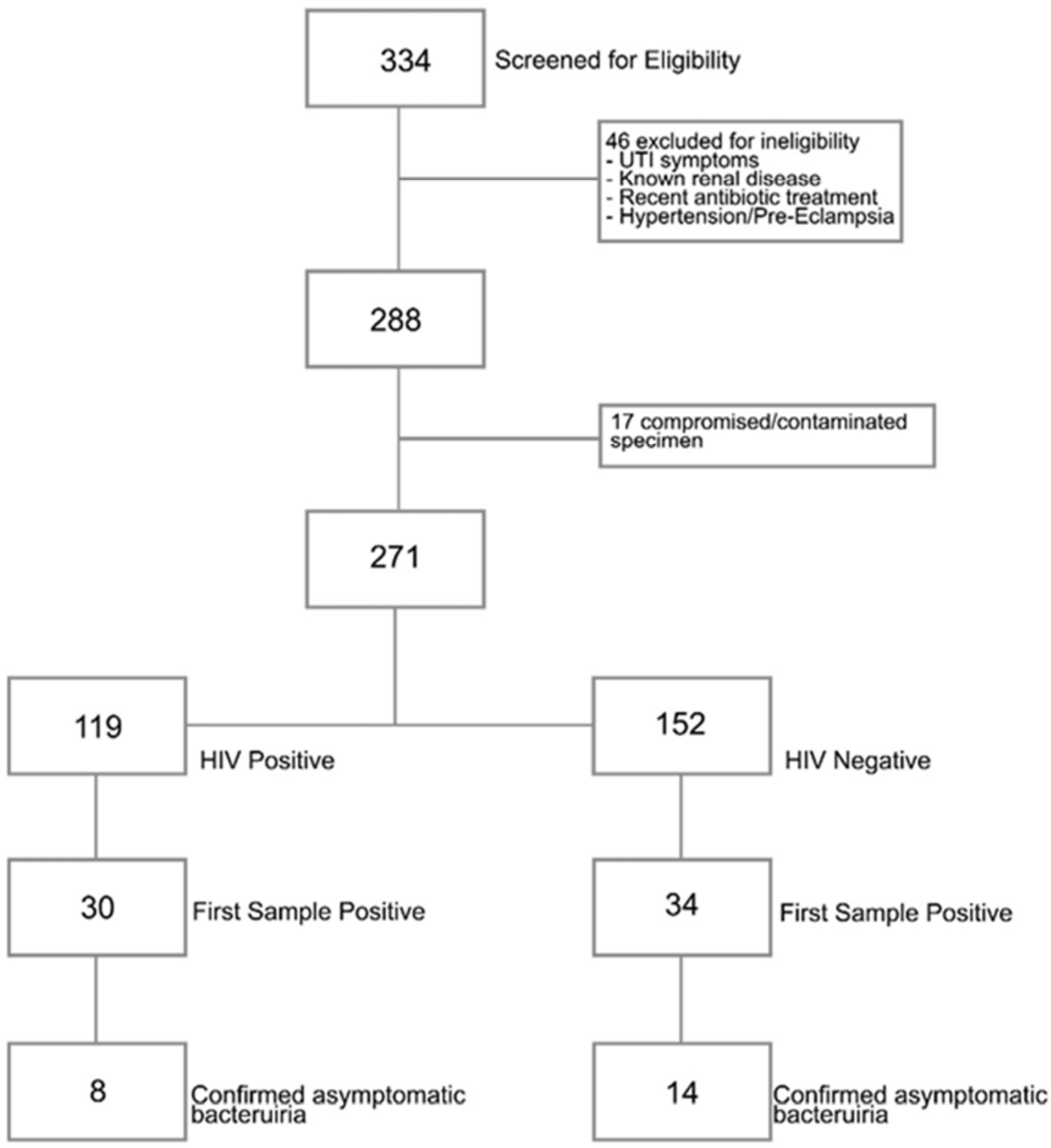

Figure 1. Study Profile. 


\section{Results}

Table 2. Asymptomatic bacteriuria and other characteristics of the respondents.

\begin{tabular}{lll}
\hline Characteristics & Frequency & Percentage n=271 \\
\hline Past history of UTI & 199 & 73.4 \\
Present & 72 & 26.6 \\
Absent & & \\
HIV Status & 152 & 56.1 \\
Negative & 119 & 43.9 \\
Positive & & \\
Husband's HIV status & 117 & 43.2 \\
Negative & 53 & 19.6 \\
Positive & 101 & 37.2 \\
Not known & 154 & 56.8 \\
Coital frequency & 59 & 21.8 \\
1-2 times a week & 8 & 3.0 \\
3-4 times a week & 7 & 2.6 \\
$5-7$ times a week & 43 & 15.9 \\
Once in 2 weeks & & \\
Once in 4 weeks or less & 41 & 15.1 \\
Asymptomatic bacteriuria & 230 & 84.9 \\
Present & & \\
Absent &
\end{tabular}

There were 271 study participants (119 HIV Positive women and 152 HIV Negative), with all HIV negatives recruited from JUTH antenatal clinic, while $96(80.7 \%)$ of HIV positive participants were recruited from the JUTH PMTCT clinic and $23(19.3 \%)$ from Faith Alive PMTCT clinic. Out of the 271 women, 64 had $10^{5}$ CFUs per $\mathrm{ml}$ of the first sample of urine, thirty-four (22.8\%) were HIV Negative, while $30(25.2 \%)$ were HIV Positive, and were required to have a repeat test to determine asymptomatic bacteriuria prevalence rate, the primary outcome of the study. Asymptomatic bacteriuria was confirmed among 22 women $(8.1 \%)$ and $8(36.4 \%)$ of them were HIV positive, while 14 (63.6\%) were HIV negative. The prevalence rate of asymptomatic bacteriuria among HIV Negative women was $9.4 \%$, and $6.8 \%$ among HIV positive women.

Table 3. Logistic regression of predictors of Asymptomatic bacteriuria among the respondents.

\begin{tabular}{|c|c|c|c|}
\hline Factors & Odds Ratio & 95\% Confidence Interval & P-value \\
\hline \multicolumn{4}{|c|}{ Age group (years) } \\
\hline$\leq 34$ & 1.21 & $0.342-4.260$ & 0.771 \\
\hline 35 and above & 1 & - & - \\
\hline \multicolumn{4}{|l|}{ Marital status } \\
\hline Single & 0.01 & $0.000>1.0 \mathrm{E} 12$ & 0.999 \\
\hline Married & 0.47 & $0.053-4.205$ & 0.500 \\
\hline Divorced & 0.01 & $0.000>1.0 \mathrm{E} 12$ & 0.999 \\
\hline Widow & 1 & - & - \\
\hline \multicolumn{4}{|c|}{ Level of education } \\
\hline None & 0.01 & $0.000>1.0 \mathrm{E} 12$ & 0.999 \\
\hline Informal & 0.01 & $0.000>1.0 \mathrm{E} 12$ & 0.999 \\
\hline Primary & 1.72 & $0.444-6.676$ & 0.432 \\
\hline Secondary & 3.30 & $1.045-10.438$ & 0.042 \\
\hline Tertiary & 1 & - & - \\
\hline \multicolumn{4}{|c|}{ Husband's Level of education } \\
\hline None & 0.01 & $0.000>1.0 \mathrm{E} 12$ & 0.999 \\
\hline Informal & 0.01 & $0.000>1.0 \mathrm{E} 12$ & 0.999 \\
\hline Primary & 0.01 & $0.000>1.0 \mathrm{E} 12$ & 0.999 \\
\hline Secondary & 1.62 & $0.618-3.897$ & 0.285 \\
\hline Tertiary & 1 & - & - \\
\hline \multicolumn{4}{|c|}{ Primary family Type } \\
\hline Monogamous & 0.49 & $0.152-1.550$ & 0.222 \\
\hline Polygamous & 1 & - & - \\
\hline \multicolumn{4}{|l|}{ Religion } \\
\hline Christianity & 0.65 & $0.269-1.566$ & 0.336 \\
\hline Islam & 1 & - & - \\
\hline \multicolumn{4}{|l|}{ Parity } \\
\hline Nulliparous & 4.26 & $0.477-37.948$ & 0.195 \\
\hline Primiparous & 4.18 & $0.418-35.222$ & 0.189 \\
\hline $2-4$ & 4.25 & $0.517-34.358$ & 0.174 \\
\hline
\end{tabular}




\begin{tabular}{llll}
\hline Factors & Odds Ratio & 95\% Confidence Interval & P-value \\
\hline$\geq 5$ & 1 & - & - \\
$\begin{array}{l}\text { Estimated gestational age at booking (weeks) } \\
\leq 13 \text { weeks }\end{array}$ & 2.18 & & 0.233 \\
$14-26$ weeks & 0.76 & $0.607-7.801$ & 0.567 \\
27 weeks and above & 1 & $0.297-1.942$ & - \\
Coital frequency & & & 0.130 \\
$1-2$ times a week & 4.78 & $0.627-37.811$ & 0.156 \\
$3-4$ times a week & 4.76 & $0.551-41.039$ & 0.999 \\
$5-7$ times a week & 0.01 & $0.000>1.0 \mathrm{E} 12$ & 0.999 \\
Once in 2 weeks & 0.01 & $0.000>1.0 \mathrm{E} 12$ & - \\
Once in 4 weeks or less & 1 & - & 0.699 \\
Husband's HIV status & & & 0.949 \\
Positive & 1.21 & $0.465-3.127$ & - \\
Negative & 0.95 & $0.272-3.309$ & $0.517-2.972$ \\
Not known & 1 & - & - \\
HIV Status & & & 0.354 \\
Positive & 1 & 1.24 & - \\
Negative & & - & \\
Past history of UTI & 0.65 & $0.264-1.610$ & - \\
Absent & 1 & - & \\
Present & & & \\
\hline
\end{tabular}

Table 4. Socio-demographic characteristics of the HIV positive respondents.

\begin{tabular}{|c|c|c|}
\hline Characteristics & Frequency & Percentage $n=117$ \\
\hline \multicolumn{3}{|l|}{ Age Group (years) } \\
\hline$\leq 34$ & 101 & 86.3 \\
\hline 35 and above & 16 & 13.7 \\
\hline Mean age & $29.2 \pm 5.0$ years & \\
\hline \multicolumn{3}{|l|}{ Marital Status } \\
\hline Single & 2 & 1.7 \\
\hline Married & 107 & 91.5 \\
\hline Divorced & 8 & 6.8 \\
\hline \multicolumn{3}{|l|}{ Religion } \\
\hline Christianity & 95 & 81.2 \\
\hline Islam & 22 & 18.8 \\
\hline \multicolumn{3}{|l|}{ Primary Family Type } \\
\hline Monogamy & 103 & 88.0 \\
\hline Polygamy & 14 & 12.0 \\
\hline \multicolumn{3}{|c|}{ Highest Level of Education Attained } \\
\hline None & 8 & 6.8 \\
\hline Informal & 1 & 0.9 \\
\hline Primary & 26 & 22.2 \\
\hline Secondary & 45 & 38.5 \\
\hline Tertiary & 37 & 31.6 \\
\hline \multicolumn{3}{|c|}{ Highest Level of Education Attained by the husband } \\
\hline None & 8 & 6.9 \\
\hline Primary & 15 & 12.8 \\
\hline Secondary & 43 & 36.8 \\
\hline Tertiary & 51 & 43.6 \\
\hline \multicolumn{3}{|c|}{ Estimated gestational age at booking (weeks) } \\
\hline$\leq 13$ weeks & 10 & 8.5 \\
\hline 14-26 weeks & 48 & 41.0 \\
\hline \multirow[t]{2}{*}{27 weeks and above } & 59 & 50.5 \\
\hline & Mean \pm SD & \\
\hline Mean gestational age at booking & $25.2 \pm 7.8$ weeks & \\
\hline \multicolumn{3}{|l|}{$\begin{array}{l}\text { Parity } \\
\text { Patis }\end{array}$} \\
\hline Nulliparous & 25 & 21.4 \\
\hline Primiparous & 33 & 28.2 \\
\hline $2-4$ & 58 & 49.6 \\
\hline$\geq 5$ & 11 & 9.4 \\
\hline
\end{tabular}

$\mathrm{SD}=$ Standard Deviation.

The participants ages range from 14-43 years, mean age was 28.5 years with standard deviation of 5.4 , modal age was
30 years and median was 29 years, and there was no significant risk conferred by age on development of 
asymptomatic bacteriuria. We analyzed ethnicity and practices like douching and coital frequency with the development of asymptomatic bacteriuria, there was no association. Education status, religion, occupation, monogamous or polygamous marriage had no association. Coital frequency did not contribute to development of asymptomatic bacteriuria, and participants who had become sexually abstinent had confirmed asymptomatic bacteriuria. History of urinary tract infections did not contribute significantly to incidence of asymptomatic bacteriuria, and it was observed that women who had no history of UTI had higher incidence of asymptomatic bacteriuria.

Staphylococcus aureus was the causative organism in $78.6 \%$ of HIV negative women, while for the HIV positive women, Escherichia coli and Staphylococcus aureus was responsible in $44.4 \%$ cases each. About $81 \%$ of isolated organisms were sensitive to all of Cefuroxime, Ciprofloxacin, Ofloxacin, Norfloxacin and Gentamycin but resistant to Chloramphenicol, Amocycillin, Nitrofurantoin, Ampicillin and Tetracycline. However, most women with confirmed asymptomatic bacteriuria (18 women, $81.8 \%$ ) refused the prescriptions of the antibiotics either because they were fine with having no treatment for an asymptomatic condition or because of the cost of the drugs or both. Counselling to recognize symptoms of UTI was provided and surveillance for symptoms and signs was intensified.

There was a sickler and a diabetic in the study, diagnosed after sample collection, were among the 22 women confirmed to have Asymptomatic Bacteriuria but the numbers were inadequate for proper analysis (2) and this cannot be generalized in spite of $P=0.0019$. There was no statistically significant difference in rates among the HIV positive and negative participants.

The study also analyzed parameters among the HIV positive women to look for association. Among the $119 \mathrm{HIV}$ positive women, 53 (44.9\%) had HIV positive husbands, 27.1\% (32) had HIV negative husbands while $28 \%$ (33) did not know the status of the husbands. There was no association between spousal/partner HIV status and development of asymptomatic bacteriuria. The duration of diagnosis/awareness of HIV positivity was less than 6 months in $45.4 \%$ of the patients, and $57(48.3 \%)$ of the HIV positive women were not on Antiretroviral Drugs (ARVs), while 61 (51.7\%) were receiving ARVs with $98.4 \%$ of these being on highly active antiretroviral drugs (minimum of three drugs from a minimum of two ARV classes). Twenty-nine (25\%) HIV Positive patients had CD4 counts of $<200$ cells $/ \mathrm{mm} 3$ (immunologic AIDS), while 73 (62.9\%) had CD4 counts of 200-499 cells/mm3, and 14 (12.1\%) had counts $>500$ cells $/ \mathrm{mm} 3$. There was no association between CD4 count and development of asymptomatic bacteriuria among the HIV positive women. The viral load was detectable ( $>100$ copies $/ \mathrm{ml})$ in $85(74.5 \%)$ and undetectable in $29(25.2 \%)$ of the HIV Positive women with no statistically significant association between absolute Viral load values and development of asymptomatic bacteriuria. However, variations between numbers of viral copies (Millions) among persons with detectable/elevated viral load, in comparison to those who had low viral load $(<1000)$ was very wide, and analysis was performed using the logarithm of the viral load values, suggesting possible association between undetectable viral load and asymptomatic bacteriuria.

Table 5. Asymptomatic bacteriuria and other characteristics of the HIV positive respondents.

\begin{tabular}{lll}
\hline Characteristics & Frequency & Percentage $\mathbf{n}=\mathbf{1 1 7}$ \\
\hline Past history of UTI & 37 & 31.6 \\
Present & 80 & 68.4 \\
Absent & & \\
Co-morbidity & 10 & 8.5 \\
Present & 107 & 91.5 \\
Absent & & \\
Coital frequency & 63 & 53.8 \\
$1-2$ times a week & 14 & 12.0 \\
$3-4$ times a week & 2 & 1.7 \\
$5-7$ times a week & 5 & 4.3 \\
Once in 2 weeks & 33 & 28.2 \\
Once in 4 weeks or less & & \\
Asymptomatic bacteriuria & 41 & 15.1 \\
Present & 230 & 84.9 \\
Absent & & \\
On ARVs & 61 & 52.1 \\
Yes & 56 & 46.9 \\
No & & \\
Duration on ARV (n=61) & 32 & 52.5 \\
$<1$ year & 29 & 47.5 \\
1 year and above & & 28.2 \\
CD4 count (cell/l) & 33 & 71.8 \\
$<200$ & 84 & \\
$\geq 200$ & &
\end{tabular}




\begin{tabular}{lll}
\hline Characteristics & Frequency & Percentage $\mathbf{n}=\mathbf{1 1 7}$ \\
\hline & Median $(\mathrm{IQR})$ & \\
Median CD4 count & $273(192.5-370.5)$ cells/ \\
Viral load (copies/ml) & & \\
$<1000$ & 47 & 40.2 \\
1000 and above & 70 & 59.8 \\
& Median (IQR) & \\
Median CD4 count & $3,035(200-15499)$ copies $/ \mathrm{ml}$ \\
Asymptomatic bacteriuria & 8 & 6.8 \\
Present & 109 & 93.2 \\
Absent & & \\
\hline
\end{tabular}

None of the 22 women with asymptomatic bacteriuria eventually showed or reported any sign of pyelonephritis and there were no records of UTI treatment in pregnancy in their antenatal charts from diagnosis until delivery.

Table 6. Logistic regression of predictors of Asymptomatic bacteriuria among the HIV positive respondents.

\begin{tabular}{|c|c|c|c|}
\hline Factors & Odds Ratio & 95\% Confidence Interval & P-value \\
\hline \multicolumn{4}{|l|}{ Age group (years) } \\
\hline$\leq 34$ & 1.12 & $0.128-9.734$ & 0.920 \\
\hline 35 and above & 1 & - & - \\
\hline \multicolumn{4}{|l|}{ CD4 count (cell/1) } \\
\hline$\geq 200$ & 0.34 & $0.041-2.908$ & 0.327 \\
\hline$<200$ & 1 & - & - \\
\hline \multicolumn{4}{|l|}{ Viral load (copies/ml) } \\
\hline$<1000$ & 0.20 & $0.023-1.646$ & 0.133 \\
\hline \multicolumn{4}{|l|}{1000 and above } \\
\hline \multicolumn{4}{|l|}{ Level of education } \\
\hline None & 0.01 & $0.000>1.0 \mathrm{E} 12$ & 0.999 \\
\hline Informal & 0.01 & $0.000>1.0 \mathrm{E} 12$ & 0.999 \\
\hline Primary & 1.46 & $0.192-11.078$ & 0.715 \\
\hline Secondary & 1.71 & $0.295-9.887$ & 0.551 \\
\hline Tertiary & 1 & - & - \\
\hline \multicolumn{4}{|l|}{ Primary family Type } \\
\hline Monogamous & 0.95 & $0.108-8.334$ & 0.962 \\
\hline Polygamous & 1 & - & - \\
\hline \multicolumn{4}{|l|}{ Religion } \\
\hline Christianity & 0.67 & $0.127-3.589$ & 0.644 \\
\hline Islam & 1 & - & - \\
\hline \multicolumn{4}{|c|}{ Estimated gestational age at booking (weeks) } \\
\hline$\leq 13$ weeks & 7.13 & $0.877-57.894$ & 0.066 \\
\hline $14-26$ weeks & 2.59 & $0.454-14.796$ & 0.284 \\
\hline 27 weeks and above & 1 & - & - \\
\hline \multicolumn{4}{|l|}{ Coital frequency } \\
\hline $1-2$ times a week & 3.37 & $0.388-29.322$ & 0.271 \\
\hline 3-4 times a week & 2.46 & $0.143-42.375$ & 0.535 \\
\hline 5-7 times a week & 0.01 & $0.000>1.0 \mathrm{E} 12$ & 0.999 \\
\hline Once in 2 weeks & 0.01 & $0.000>1.0 \mathrm{E} 12$ & 0.999 \\
\hline Once in 4 weeks or less & 1 & - & - \\
\hline \multicolumn{4}{|l|}{ On ARVs } \\
\hline Yes & 0.63 & $0.144-2.784$ & 0.546 \\
\hline No & 1 & - & - \\
\hline \multicolumn{4}{|l|}{ Duration on ARVs } \\
\hline$\leq 1$ year & 0.50 & $0.111-2.222$ & 0.359 \\
\hline Abovel year & 1 & - & - \\
\hline \multicolumn{4}{|l|}{ Past history of UTI } \\
\hline Absent & 0.43 & $0.102-1.842$ & 0.258 \\
\hline Present & 1 & - & - \\
\hline
\end{tabular}

The analysis of the logarithm of the viral load revealed that women with very high viral counts were more at risk of developing asymptomatic bacteriuria. 


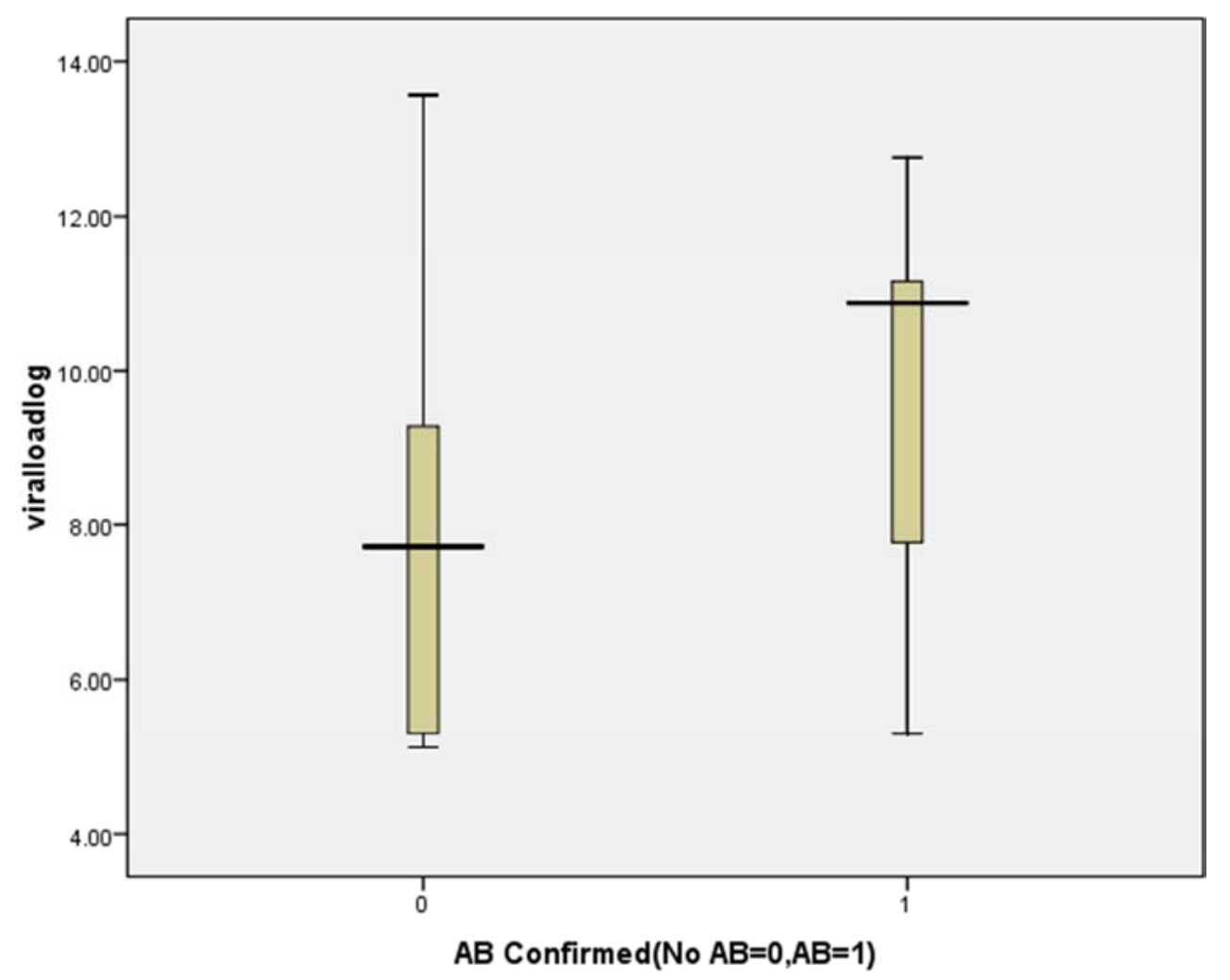

Figure 2. AB versus Log of Viral Load among HIV Positive pregnant women.

\section{Discussion}

This study showed a prevalence of $8.1 \%$ of Asymptomatic Bacteriuria among the study population, which was higher than 4.8\% obtained by Mandara and Shittu at Zaria [17] and $5 \%$ obtained by Kazemier et al in Netherlands [34]. It is similar to $8 \%$ obtained by Oyetunji et al at Sokoto [13] but less than $14 \%$ obtained by Nnatu [23] and Okonofua [24] in their studies, and that obtained by Sonkar et al [35] It was at completely at variance with the $86 \%$ rate obtained by Akerele in Benin city [20]. No study was found that compared between HIV positive and HIV negative study participants in pregnancy.

Factors like past UTI, HIV status, duration of time on ARVs did not predispose significantly to development of Asymptomatic Bacteriuria. The organisms obtained were consistent with those of other studies [8, 10, 12, 15, 26]. Asymptomatic Bacteriuria had a higher incidence among women at 14-28 weeks gestation, but gestation age was not statistically significant as a risk factor.

Two women had diabetes mellitus and SCD respectively and both had Asymptomatic Bacteriuria, which was in keeping with findings in previous studies as the two conditions predispose to infection [26]. Establishing definite association between Asymptomatic Bacteriuria and these disorders will however require larger studies.

Staphylococcus aureus predominated (78.6\%) among HIV negative participants who had asymptomatic bacteriuria, while for HIV positive women, Escherichia coli and
Staphylococcus aureus were aetiologic organism in $44.4 \%$ each of women found to have asymptomatic bacteriuria. Another study found $71 \%$ of Escherichia coli and $10 \%$ Staphylococcus aureus among the participants [34] but this was among HIV negative persons.

The sensitivity pattern ranged from ciprofloxacin, Cefuroxine, a cephalosporin that is safe in pregancy, as well as Ofloxacin and Norfloxacin (both Quinolones and harmful in pregnancy) $[15,19,26]$. Organisms were resistant to Penicillins, Nitrofurantoin, Tetracycline and Gentamycin. In the study by Kazemier et al [34], most microorganisms $(237 / 255$ [93\%]) were sensitive to nitrofurantoin which is a readily available, simpler and cheaper drugs compared to cephalosporin, while Sonkar et al found resistance to ampicillin in $100 \%$ of cases an d $61 \%$ of the organisma were E.coli [35].

However, laboratory and antibiotics costs, clinic staff, cost of patients return clinic trips to provide urine and obtain results all contribute challenges to screening for asymptomatic bacteriuria in pregnancy [19].

No woman reported symptoms of acute pyelonephritis even when they did not receive antibiotic treatment. However, this may be subjective since patients can procure drugs in community chemists without reporting to hospital. Studies by Wing et al [36] found $0.5 \%$ of women were admitted to hospital for acute pyelonephritis, and others documented $21 \%$ of untreated pyelonephritis in pregnancy [37]. Other possible reasons for low rates of pyelonephritis include our exclusion of women with some disorders since so that we focused on an otherwise low-risk population of women. Therefore, although 
our study population was small, we question a policy of routine asymptomatic bacteriuria screening among pregnant women. However, this calls for further investigation and possibly randomized control trials among HIV positive women with very high viral load and women with medical disorders like diabetes mellitus and sickle cell disease, who had higher incidence of asymptomatic bacteriuria in this study.

An antenatal study suggested that bacteriuria was highest between the $9^{\text {th }}$ and $17^{\text {th }}$ weeks of pregnancy [8], but proposed the $16^{\text {th }}$ week as optimal time for a simple screen of bacteriuria calculated from the number of bacteria free gestational weeks gained by treatment $[8,26]$. This will be difficult as many women book late for ANC in our environment and others do not receive antenatal care at all [38].

Generally, controversy still exists about benefits of routine screening [8], but some workers conclude that screening for Asymptomatic Bacteriuria among pregnant women, though cumbersome, is associated with better pregnancy outcomes when detected and treated $[15,17,21,26]$. This is not consisted with what we found in his study.

\section{Conclusion and Recommendations}

The incidence of Asymptomatic Bacteriuria is $8.1 \%$ in this environment, and HIV positivity confers no additional risk for those who are on ARVs and virologically suppressed. Antibiotic resistance to various aetiologic organisms isolated in Asymptomatic Bacteriuria are emerging and on the increase. In this study, development of pyelonephritis is not demonstrable even without treatment, while Smaill et al concluded in their work that antibiotic treatment may be effective in reducing risk of pyelonephritis in pregnancy but confidence in the effect estimate is limited in view of the low certainty of evidence [39].

With prevalence rate of $8.1 \%$ and absence of clinical pyelonephritis, we do not recommend routine screening for Asymptomatic Bacteriuria in all pregnant women, especially in our environment. Larger studies are required to determine association with Asymptomatic Bacteriuria with SCD, Diabetes mellitus and HIV positive women with high viral load. Studies are required to assess occurrence of secondary outcomes like preeclampsia, anaemia, preterm delivery to determine the group of women that require prioritization for screening during antenatal care. This will have to overcome the challenge of low rates of hospital delivery.

\section{Acknowledgements}

The Medical Education Partnership Initiative in Nigeria (MEPIN) project supported data analysis and writing of this paper. It was funded by Fogarty International Center, the Office of AIDS Research, the National Human Genome Research Institute of the National Institute of Health, The Health Resources and Services Administration (HRSA) and the Office of the US Global AIDS Coordinator under Award Number R24TW008878.

\section{References}

[1] Society of Gynecology and Obstetrics of Nigeria (SOGON). Manual on the management of HIV/AIDS in pregnancy. SOGON, 2005; 1-34.

[2] Ladipo O A. "Millennium development goals: a reality or a mirage". Late Professor Olusola Ojo SOGON Second memorial lecture. Daily Graphics Limited, 2005; 1-45.

[3] Bruyn M. Living with HIV: Challenges in reproductive Health Care in South Africa. African Journal of Reproductive Health, Vol 8 No 1, April 2004; 92-98.

[4] Ogunbode O. Acquired Immune Deficiency Syndrome and Reproductive Health. In: Ogunbode Toye (Ed), Medical Disorders in Tropical Obstetrics, Evans Brothers (Nigerian Publishers) Limited, 1997; 161-168.

[5] Damale NKR. Human Immune Deficiency Virus in Pregnancy. In: Kwawukume EY, Emuveyan EE (Ed) Comprehensive Obstetrics in the Tropics. Asante and Hittscher Printing Press Limited, Dansonam. 2002; 38-46.

[6] Fawole OA, Sotiloye OS, Hunyinbo KI, Fawole OI, Oladimeji AO, Durodola A, et al. HIV in Pregnancy: Experience at Abeokuta, Nigeria. Trop J Obstet Gynaecol, 19 (1), April 2002; 21-24.

[7] Okany CO, Akanmu AS. Clinical manifestations of HIV/AIDS. Archives of Ibadan medicine-HIV/AIDS. Vol 5, Nos 1 \$2, April/October 2004; 7-13.

[8] Addo VN. Urinary Tract Infections in Pregnancy. In: Kwawukeme EY, Emuveyan EE (Ed). Comprehensive Obstetrics in the Tropics. Asante and Hittscher Printing Press Limited, Dansonam. 2002; 261-267.

[9] Ogunbode O. Renal diseases in Pregnancy. In: Ogunbode Toye (Ed), Medical Disorders in Tropical Obstetrics. Evans Brothers (Nigerian Publishers) Limited. 1997; 35-49.

[10] Onuh SO, Umeora OUJ, Azikem M, Igberase GO, Onyia OP, Osahon E, Okpere E. Bacteriological Patterns of Urinary Tract Infections in Pregnancy in Benin city. Trop J Obstet Gynaecol, 20 (Suppl. 1), November 2003; S13.

[11] Campbell S, Lees C (Ed). Urinary Tract infection in Pregnancy. Obstetrics by Ten Teachers, $17^{\text {th }}$ Edition, Astra Zeneca, 2000; 201.

[12] Ezechi OC, Fasubaa OB, Dare FO. Antibiotic sensitivity patterns of Microbial Isolates from the Urine of Pregnant women with Urinary Tract Infections. Trop J Obstet Gynaecol, 20 (2), October 2003; 113-118.

[13] Oyetunji JA, Ahmed Y, Nwobodo EI, Ekele BA, Audu Airede LR. Asymptomatic Bacteriuria in pregnancy in Sokoto, Nigeria. Trop J Obstet Gynaecol 22 (Suppl. 1), November 2005; S23.

[14] Raz R. Asymptomatic bacteriuria. Clinical Significance and management. International Journal of Antimicrobial Agents 17 (2003) 545-547. Available at http://www.ischemo.org.

[15] Kremerys S, Hromec J, Demesova D. Treatment of Urinary Tract Infection in Pregnancy. International Journal of Antimicrobial Agents 17 (2001); 279-282. Available at http://www.ischemo.org. 
[16] Herera JA, Chaudhuri G, Lopez-Jar-amillo P. Is Infection a major risk factor for Pre-Eclampsia. Medical Hypothesis (2001) $57 \quad$ (3), 393-397. Available at http://www.idealibrary.com.

[17] Mandara MU, Shittu SO Asymptomatic Bacteriuria in Antenatal Patients at ABUTCH, Zaria, Nigeria. Trop J Obstet Gynaecol, Vol 16 No 1. 1999; 41-45.

[18] Smith GW, Brumfi HC. Urinary Tract Infection in Pregnancy. Post Graduate Doctor-Africa 6, 1984; 231-254. Available at http://www.ischemo.org.

[19] Maclean AB. Urinary Tract Infection in Pregnancy. International Journal of Antimicrobial Agents, 17 (2001); 273-277.

[20] Akerele J, Abhulimen P, Okonofua F. Prevalence of Asymptomatic Bacteriuria among Pregnant women in Benin city, Nigeria. Journal of Obstetrics and Gynaecology, 2001; Vol 31, No 2, 141-144.

[21] Kunin CM. Screening for asymptomatic bacteriuria during pregnancy-reconsidered. International Journal of Antimicrobial Agents 17 (2001) 273-277.

[22] Kass EH. Maternal Urinary Tract Infection. New York State J. Med., 1962, 2822-2826.

[23] Nnatu S, Essien EE, Akinkugbe A, Odum CU. Asymptomatic bacteriuria in pregnant Nigerian patients. Clinical and experimental Obstetrics and Gynaecology, 16, 1989; 126-129.

[24] Okonofua FF, Adeniran A, Okonofua B. Incidence and Pattern of asymptomatic Bacteriuria of Pregnancy in Nigerian women. Nig. Med. Pract. 17 (3) 35-38.

[25] Adinma JIB, Adinma E. Priorities on HIV/AIDS research. Trop J Obstet Gynaecol Vol 18 Suppl 1, Nov 2001; 1 .

[26] Robson SC. Asymptomatic bacteriuria. In: Edmunds DK (Ed). Dewhurst's Textbook of Obstetrics and Gynaecology for Postgraduates (6 ${ }^{\text {th }}$ Edition). Blackwell Science 1999; 183-185.

[27] Rouse DJ, Andrews WW, Goldenberg RL. Screening and Treatment of Asymptomatic bacteriuria of pregnancy to prevent pyelonephritis: a cost effectiveness and cost benefit analysis. Obstet Gynaecol 1995; 86: 119-123.

[28] Ezegwui HU, Ikeme AC, Onwasigwe CN. Attitude of Antenatal Patients in Enugu towards HIV screening. Trop J Obstet Gynaecol, 22 (2), October 2005, 156-163.

[29] Spence MR, Harwell TS, Jones K. Asymptomatic bacteriuria in women infected with HIV-1. $11^{\text {th }}$ International AIDS Conference, Vancouver, British Columbia. July 7-12, 1996 at http:/www.aegis.com/conferences/iac/1996/ThB4190.html.
[30] Onakewhor JUE. Human Immunodeficiency Virus (HIV) infection/AIDS in pregnancy. In: Eugene Okpere (Ed), Clinical Obsetrics, Uniben Press, Benin City, 2003; 84-95.

[31] Centre for Disease Control and Prevention: Public Health Service Task Force (2002): Recommendation for the use of Antiretroviral Drugs in pregnant HIV-1 infected women for maternal health and interventions to reduce perinatal HIV-1 transmission in the United States. Mortality and Morbidity Weekly Report (MMWR) 2002; 51 (NORR-18): 1-30.

[32] Omobosola A, Keith Henry. Complications of Antiretroviral therapy. Archives of Ibadan Medicine HIV/AIDS, AprilOctober 2004; 52-57.

[33] United States Department of Health and Human Services, 2003 Guidelines for the use of antiretroviral agents in HIV-1 infected adults and adolescents. Rockville, Maryland: HIV/AIDS Treatment Information Service. Available at aids info.nih.gov.

[34] Kazemier BM, Koningstein, FN, Schneeberger C, Ott A, Bossuyt PM, de Miranda E, Vogelvang TE, Verhoeven CJM, Langenveld J, Woiski M, Oudijk MA, van der Ven JEM, Vlegels MTW, Kuiper PN, Feiertag N, Pajkrt E, de Groot CJM, Mol BWJ, Geerlings SE. Maternal and neonatal consequences of treated and untreated asymptomatic bacteriuria in pregnancy: a prospective cohort study with an embedded randomized controlled trial. Lancet Infect Dis 2015; 15: 1324-33. Published Online August 6, 2015 http://dx.doi.org/10.1016/ S1473-3099(15)00070-5.

[35] Sonkar N, Banerjee M, Gupta S, Ahmad A: Asymptomatic Bacteriuria among Pregnant Women Attending Tertiary Care Hospital in Lucknow, India. Dubai Med J 2021; 4: 18-25. doi: $10.1159 / 000513626$.

[36] Wing DA, Fassett MJ, Getahun D. Acute pyelonephritis in pregnancy: an 18-year retrospective analysis. Am J Obstet Gynecol 2014; 210: 219-16.

[37] Smaill F, Vazquez JC. Antibiotics for asymptomatic bacteriuria in pregnancy. Cochrane Database Syst Rev 2007; 2: CD000490.

[38] Eze JN, Iloabachie GC, Okaro JN, Okafor NH. Review of Gram Multiparity at the University on Nigeria Teaching Hospital, Enugu. Trop J Obstet Gynaecol, Vol 20, Suppl 1, Nov 2001, S 12.

[39] Smaill FM, Vazquez JC. Antibiotics for asymptomatic bacteriuria in pregnancy. Cochrane Database of Systematic Reviews 2019, Issue 11. Art. No.: CD000490. DOI: 10.1002/14651858.CD000490.pub4. Accessed 18 June 2021. 